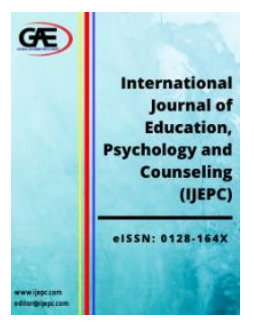

\author{
INTERNATIONAL JOURNAL OF \\ EDUCATION, PSYCHOLOGY \\ AND COUNSELLING \\ (IJEPC) \\ www.ijepc.com
}

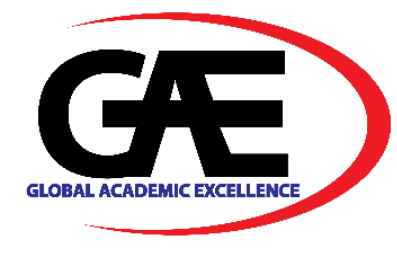

\title{
INVESTIGATING ENGLISH WRITING PROBLEMS AMONG HIGH ACHIEVER POST-UPSR LEARNERS IN SABAH
}

\author{
Dg Nursazwani Daud ${ }^{1}$, Wardatul Akmam Din ${ }^{2 *}$, Noraini Said ${ }^{3}$, Suyansah Swanto ${ }^{4}$ \\ $1 \quad$ Faculty Psychology and Education, Universiti Malaysia Sabah, Malaysia \\ Email: dg.nursazwani@gmail.com \\ 2 Faculty Psychology and Education, Universiti Malaysia Sabah, Malaysia \\ Email:wardadin@ums.edu.my \\ $3 \quad$ Faculty Psychology and Education, Universiti Malaysia Sabah, Malaysia \\ Email: noraini.said@ums.edu.my \\ $4 \quad$ Faculty Psychology and Education, Universiti Malaysia Sabah, Malaysia \\ Email: suyansah@ums.edu.my \\ Corresponding Author
}

\section{Article Info:}

Article history:

Received date: 11.09.2021

Revised date: 10.10.2021

Accepted date: 15.11 .2021

Published date: 30.11 .2021

\section{To cite this document:}

Daud, D. N., Din, W. A., Said, N., \& Swanto, S. (2021). Investigating English Writing Problems Among High Achiever Post-UPSR Learners in Sabah. International Journal of Education, Psychology and Counseling, 6 (43), 30-39

DOI: $10.35631 /$ IJEPC.643003

This work is licensed under CC BY 4.0

\begin{abstract}
:
The purpose of the study was to investigate the writing problems faced by the Post-UPSR learners during their primary school years. The data was obtained from 217 high achiever learners who scored an A on the UPSR. These learners, who had completed primary schools and taken the UPSR exam, are now enrolled in secondary schools as Form 1 learners. The method used is a quantitative study. A questionnaire was used as the instrument in the study. The analysis of the study uses SPSS which involves frequency and percentage. The data revealed that Malaysian ESL primary school learners struggle with writing tasks, particularly due to insufficient of vocabulary knowledge. The findings of the study will be valuable to ESL researchers and educators in assisting learners with their writing difficulties. Teachers or researchers can develop appropriate solutions to the issues once the writing issue has been identified.
\end{abstract}

\section{Keywords:}

Writing Problem, Vocabulary, Post-UPSR, High Achiever, ESL Context 


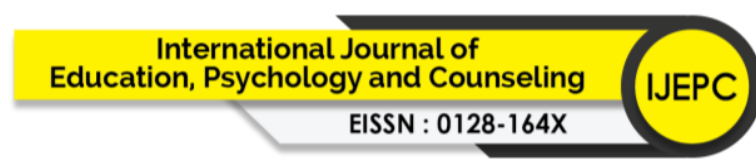

Volume 6 Issue 43 (November 2021) PP. 30-39

DOI 10.35631/IJEPC.643003

\section{Introduction}

Special Issue: Issues and Challenges in English Education

English is practised as a second language in all Malaysian primary schools, therefore, it is crucial for the young learners to master the subject in order to learn English writing as one of language skills. In the Malaysian Education Blueprint 2013-2025, the Ministry of Education has expressed that the aim of English literacy is to acquire a minimum pass of $70 \%$ with a minimum credit (Ministry of Education Malaysia, 2013).

In the primary school level, the Year 6 learners were obliged to take the Primary School Achievement Test, which also known as 'Ujian Pencapaian Sekolah Rendah' (UPSR), but the test was halted in 2021. According to the past candidates of UPSR, English has been one of the most challenging subject particularly, the writing component that is often been regarded as a vital and comprehensive skill that aids in the development of vocabulary, grammar, thinking, planning, editing, revising, and other factors (Lim, Melor \& Embi, 2017).

Likewise, writing encourages learners to think, requires them to focus and organise their thoughts, and improves their ability to synthesise, analyse, and criticise as it emphasises the importance of continuous learning, thinking, and reflecting in the English language learning (Maghsoudi \& Haririan, 2013; Lim et al., 2017). Writing also encompasses all of an individual's knowledge, skills, and experience because it employs a mental-processing skill that allows individual learners to communicate and learn more effectively, as well as improve their writing skills by controlling their thinking skills as a permanent learning component (Duran \& Karatas, 2019).

The purpose of this study is to discover the writing issues that learners encounter after six years of learning English in primary school. This study is significant since it identifies the roots of writing difficulties, which will aid teachers in finding solutions to the problem. It is also a teacher's role to teach proper grammar and language usage when teaching writing in primary school. This is supposed to help learners develop their ability to improvise, particularly in writing.

\section{Research Problem}

The major concerns that learners have in writing are their inability to produce ideas, difficulties in structuring paragraphs around the topic, and selecting words due to a lack of vocabulary (Firmansyah, 2015). Likewise, it is integrated with other language skills and involves a thorough understanding of grammar, appropriate word or phrase choice, writing mechanics, organisational skills as well as writing styles (Melor \& Chan, 2016). Besides, ESL learners face difficulty to understand word context and meaning due to the difference between writing in the first and second languages (Ghabool et al., 2012).

Writing skills are the most difficult to develop (Can \& Yavuz, 2017) in which the problem of writing difficulties started in childhood (Duran \& Karatas, 2019). For instance, individuals with difficulty in the transfer of knowledge are known to have challenges with spelling (Bayraktar \& Seckin, 2012). In addition, if letters, phrases, sentences, and paragraphs are not written according to the standard, inaccurate writing may result (Duran \& Karatas, 2019). Plus, learners with writing problems may struggle with one or more components of the writing process, such as grammar, conventions, punctuation, capitalization, spelling, and 


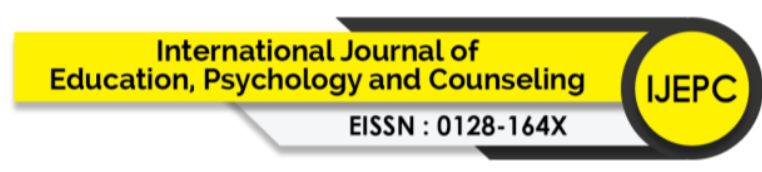

Volume 6 Issue 43 (November 2021) PP. 30-39

DOI 10.35631/IJEPC.643003

Special Issue: Issues and Challenges in English Education

various writing features. ESL students, in particular, have difficulty acquiring English word order or word forms (Ghabool et al., 2012).

\section{Research Objective and Question}

The specific objective of the study is as follows:

i. To examine the problems faced by the Post-UPSR learners when writing in English during their primary school phase.

The research question of this study is as follows:

i. What are the problems faced by the Post-UPSR learners when writing in English during their primary school phase?

\section{Literature Review}

There are three points will be discussed in literature review consists of writing skills, writing problems, and writing problems in Malaysian primary schools.

\section{Writing Skills}

Writing is one of the language skills which will never be extinct in education since it is crucial in language studies and other academic fields as well (Riswanto \& Putra, 2012; Lim et al., 2017). Nonetheless, writing is one of the most complex skills for learners to acquire because it necessitates a variety of skills and conventions such as idea organisation and development, accurate use of vocabulary in eliminating ambiguity of meaning, and appropriate use of grammatical devices (Melor, Norazah, Hadi, Amin \& Zeinab, 2013).

Writing requires the writer to carefully select vocabulary and possess a thorough understanding of grammatical patterns to construct sentence structures that are relevant to the subject matter and it entails composing i.e. the ability to tell or retell information (Lim et al., 2017). Dunsmuir, Kyriacou, Batuwitage, Hinson, Ingram and O'Sullivan (2015) describe writing as the area involving idea development, vocabulary, sentence structure and grammar (writing processes), spelling, punctuation, as well as handwriting (mechanics). It can be concluded that writing is a pivotal skill because communication is not solely done orally but also in written. Writing allows writers to practise more with the language since the skills are intertwined with other linguistic skills (Lim et al., 2017).

\section{Writing Problems}

The writing task becomes challenging because there are so many theoretical and practical issues to consider. In the ESL classroom, all of these parts of the writing process have been a great achievement. As a result, a teacher needs to assist learners in recognising and overcoming writing issues (Ghabool et al., 2012; Halipah \& Kamarul, 2020).

The solution to learners' writing issues is a well-written essay with suitable content, vocabulary, spelling, grammar, and punctuation as well (Tse, 2014). Time is taken into consideration when composing a composition where learners could properly begin with the introduction, the body parts and time to make errors and rectify them. Teachers require time to give feedback on grammar problems, content and organisation when reviewing a piece of writing (DeLuca \& Bellara, 2013; Halipah \& Kamarul, 2020). 


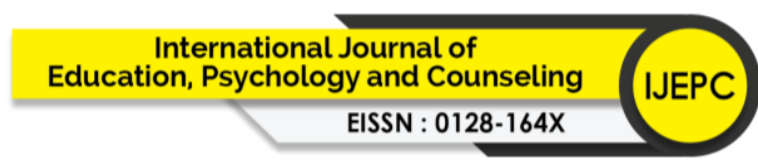

Volume 6 Issue 43 (November 2021) PP. 30-39

DOI 10.35631/IJEPC.643003

Special Issue: Issues and Challenges in English Education

Learners are frequently in a situation where they understand how to create sentences but have difficulty doing so during the writing process (Nyang'au, 2014). Learners rarely indicate the development of writing and the strategies that can help them become better writers. As a result, English teachers should pay attention to their learners' writing strategies in their papers (Maarof \& Murat, 2013; Halipah \& Kamarul, 2020).

According to Ghabool and Kashef (2012), there is a focus on learners who have writing issues, in which they could struggle with one or more aspects of writing abilities. They should know how to use grammar because it is necessary for them to be able to write (Krishnasamy, 2015; Halipah \& Kamarul, 2020). Both learners and staff teachers must recognize and identify such difficulties in writing for learners' writing to improve. Furthermore, their writing may assist them to determine whether or not what they have written is grammatically correct. Writing skills should take into account strong sentence patterns and the avoidance of errors (Halipah \& Kamarul, 2020).

\section{Writing Problems in Malaysian Primary Schools}

A critical review of the past studies on English language learning in Malaysian schools context indicates that the first language (Bahasa Malaysia) interferes considerably with the second language learning. The interference of the first language (Bahasa Malaysia) which makes it difficult to learn the second language. Additionally, applying proper English grammar is a major issue in Malaysian learners' writing, with the three most common grammatical errors comprise of the misuse of articles, verb to be, and subject-verb agreements (Ghabool et al., 2012).

Apart from that, learners find writing in English difficult since it requires them to use a range of cognitive and linguistic processes that they are unfamiliar with. Some young English learners struggle to generate and organise ideas, and they struggle to produce good writing pieces due to a lack of expertise of how to form and organise ideas, as well as demonstrate their work in a cohesive manner (Selvaraj \& Azlina, 2019). Another common writing issue among ESL students is the lack from certain abilities such as appropriate grammar, conventions, punctuation, capitalization as well as spelling (Ghabool et al. 2012; Ramasamy \& Abdul Aziz, 2018). Furthermore, according to some research, a lack of pedagogical understanding of writing among teachers, and an inability to choose the appropriate strategy for teaching writing, are other issues that have resulted in the emergence of incompetent writers among ESL learners (Melor \& Chan, 2016; Selvaraj \& Azlina, 2019). Despite this, the data reveals a drop in the percentage of learners passing the UPSR English Writing paper, from $77 \%$ in 2016 to $73.6 \%$ in 2017, four years after the Malaysian education Blueprint (2013-2015) was introduced (Aziz, 2018).

When it comes to learning to write, each learner may encounter different challenges since each individual learner is unique in their own way. These obstacles will hinder their progress toward producing a quality piece of writing (Moses \& Maslawati, 2019). A lack of vocabulary has made it difficult for learners to learn writing as vocabulary is the most crucial facet in forming sentences, and it is at the heart of good writing skills (Asep, 2014; Nor Hani, Maslawati, Melor \& Azizah, 2017; Moses \& Maslawati, 2019). Learners generally always use spoken and written words to convey their thoughts, opinions, and feelings with those 


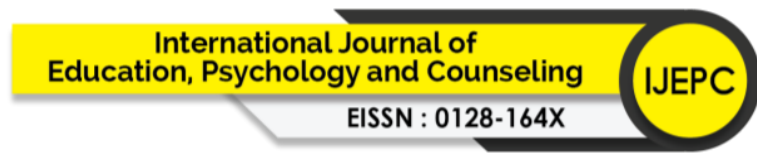

Volume 6 Issue 43 (November 2021) PP. 30-39

DOI 10.35631/IJEPC.643003

Special Issue: Issues and Challenges in English Education around them on a daily basis. A strong vocabulary base can aid them in communicating their ideas verbally or in writing.

Grammar is also a problem for some elementary school learners. In writing, grammar is really crucial as it gives information that aids readers in grasping the meaning of the text as a structure that reveals the writer's comprehensive meaning. Grammar also discusses how words are formed and structured (morphology) and how they are organised in sentences (syntax). Learners can experience anxiousness when attempting to construct sentences with proper grammar due to their insufficient knowledge of grammar. Learners tend to make mistakes in subject-verb agreement, pronouns, tenses, articles, prepositions, and basic sentence constructions (Fareed, Ashraf \& Bilal, 2016; Moses \& Maslawati, 2019).

When learning to write, learners also have to worry about their spelling (Nyang'au, 2014). Children will learn to write more effectively if they have strong spelling skills. Those who struggle with spelling will not be able to progress. Learners have a habit of spelling words based on how they sound, which results in inaccurate spelling (Afrin, 2016). For example, they frequently add or remove letters from words. Apparently, learners who memorise their spelling would have better spelling (Nyang'au, 2014).

Another problem in learning to write is learners' readiness (Foster, 2015). In fact, readiness is essential to successfully complete a task (Winarso, 2016). Physical and mental preparedness are two distinct sorts of readiness that students would struggle to write without. Foster (2015) claims that stimulating and attracting learners' attention can aid their preparedness to study writing. Next, a lack of motivation is also another issue that learners confront. Without motivation, they may not be interested to learn. Gbollie and Keamu (2017) stress about the important of motivation in increasing learners' learning outcomes. Learners will progress further in their learning process if they obtain positive reinforcement.

\section{Methodology}

This part addresses the research design, sample of the study, data collection and data analysis.

\section{Research Design}

The current study employs quantitative research design to answer a specific research question. The statistical data should reflect the clarity of the analysis of the samples' feedback or responses. The questionnaires evaluated by some experts before being distributed in the real study. The questionnaires were then modified based on their comments and recommendations. The questionnaires were then disseminated for the pilot study to see if they were appropriate and responsive by the 30 Form One learners at a secondary school in Penampang, Sabah. After the respondents had completed the questionnaire for one day, certain modifications were implemented based on their feedback.

After the pilot test, the questionnaires were distributed to four different secondary schools in Kota Kinabalu for the actual study. These schools were selected based on a ranking list of high-ranking schools with high-achieving learners, which revealed that the majority of the best schools with outstanding outcomes were located in Kota Kinabalu. The researcher met with school administration before distributing questionnaires in the real study to verify the 


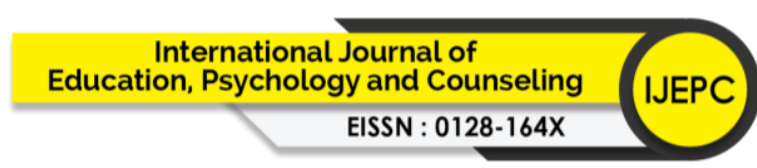

Volume 6 Issue 43 (November 2021) PP. 30-39

DOI 10.35631/IJEPC.643003

Special Issue: Issues and Challenges in English Education authorization letter that had been sent through email the plan to conduct questionnaires at their schools.

\section{Sample of the Study}

Secondary school learners were requested to complete the questionnaire that will be used to take into account of writing problems. A total of 267 learners from four secondary schools in Sabah participated in the implementation of the questionnaires. These learners meet the purposeful sampling requirements as high achievers who scored an A in UPSR English writing. Purposeful sampling entails locating and selecting individuals or groups of individuals who are particularly educated or experienced about a topic of interest (Cresswell \& Clark, 2011).

\section{Data Collection}

The questionnaire with closed-ended questions about writing difficulty was used in this study. Participants from four schools completed the surveys after two weeks. The questionnaire's general goals include identifying the writing problems that Post-UPSR learners have during their primary school years. This questionnaire was adapted from Yaseen's (2016) six-question questionnaire, which he revised from Runqing and Manchun's questionnaires (2004). The questionnaire asks about the learners' writing problem, their perspectives of writing and the prevailing teaching methods utilised by teachers in writing classes. The instrument's face validity was determined by a jury of experts (Yaseen, 2006; Azwani, Nor'ain, \& Noor, 2016). The researcher has made various adjustments to match the educational needs of Malaysian learners.

\section{Data Analysis}

Data analysis is a systematic search for meaning as a way to process qualitative data so that what has been discovered can be interpreted and conveyed to others (Hatch, 2002). In this study, the data was analysed with the IBM SPSS Statistics 28 software programme to determine the frequency and percentage of sample descriptions.

\section{Findings and Discussion}

Five items were included in the writing difficulties questionnaire, which included a four-point scale for each question.

\section{Question 1}

The first question asked how much the learners liked writing in English, particularly during their primary school phase.

Table 1: How Much Do You Like Writing In English?

\begin{tabular}{cccccc}
\hline & & Frequency & Percent & Valid Percent & Cumulative Percent \\
\hline Valid & Enjoy & 140 & 64.5 & 65.4 & 65.4 \\
& It is ok & 58 & 26.7 & 27.1 & 92.5 \\
& Dislike & 16 & 7.4 & 7.5 & 100.0 \\
Total & 214 & 98.6 & 100.0 & \\
Missing & System & 3 & 1.4 & & \\
Total & 217 & 100.0 & & \\
\hline
\end{tabular}




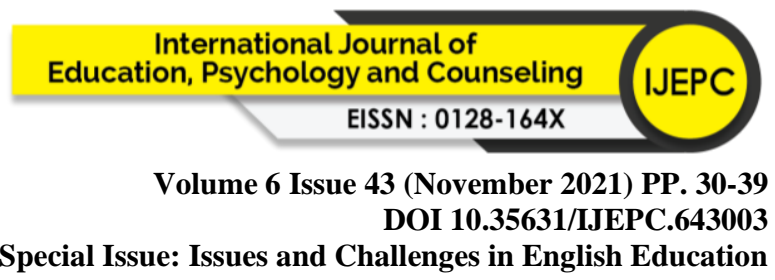

Special Issue: Issues and Challenges in English Education The results show that $64.5 \%$ of respondents claimed they 'enjoy' writing in English, $26.7 \%$ answered 'it is ok', 7.4\% answered they 'dislike' it, and none said they 'hate' it. As a result, the majority of Post-UPSR learners prefer to write in English.

\section{Question 2}

The second question asked if the writing instruction taught in school during their primary schools help to improve their writing skills.

\begin{tabular}{cccccc}
\multicolumn{2}{c}{ Table 2: Is The Writing Instruction Taught In Your School During Your Primary } \\
School Help To Improve Your Writing Competence?
\end{tabular}

The results show that $26.3 \%$ of the learners stated it was "very useful," $32.3 \%$ said it was "helpful," 23.5\% answered it was "a little helpful," and 16.6\% answered it was "unhelpful." It appears that the majority of Post-UPSR learners believed that writing instruction provided throughout their primary school years was beneficial in strengthening their writing skills.

\section{Question 3}

The third question asked about the respondents' perspectives whether their schools attach great importance to the teaching of English writing during their primary schools.

Table 3: Do You Think That Your School Attaches Great Importance To The Teaching Of English Writing?

\begin{tabular}{cccccc}
\hline & & Frequency & Percent & Valid Percent & Cumulative Percent \\
\hline \multirow{6}{*}{ Valid } & Yes, it does & 118 & 54.4 & 55.1 & 55.1 \\
& Sometimes & 56 & 25.8 & 26.2 & 81.3 \\
& Not much & 40 & 18.4 & 18.7 & 100.0 \\
\multirow{2}{*}{ Missing } & Total & 214 & 98.6 & 100.0 & \\
\cline { 2 - 5 } & System & 3 & 1.4 & & \\
\hline
\end{tabular}

According to the results, $54.4 \%$ of the learners answered 'Yes, it does,' $25.8 \%$ stated 'Sometimes,' 18.4\% indicated 'Not much,' and none replied 'No, it doesn't.' The majority of Post-UPSR learners believe that English writing was valued highly in their primary schools. 


\section{Question 4}

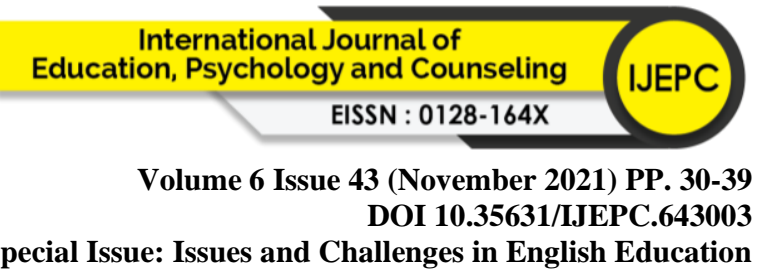

The fourth question asked how many writing texts did the respondents write according to the tasks allocated by their English teachers in one school term during their primary schools.

Table 4: How Many Writing Texts Did You Write According To The Tasks Assigned By The Teacher In One School Term?

\begin{tabular}{cccccc}
\hline & Frequency & Percent & $\begin{array}{c}\text { Valid } \\
\text { Percent }\end{array}$ & $\begin{array}{c}\text { Cumulative } \\
\text { Percent }\end{array}$ \\
\hline Valid & None & 3 & 1.4 & 1.4 & 1.4 \\
& 1-2 passage(s) & 43 & 19.8 & 20.1 & 21.5 \\
& 3-5 passages & 110 & 50.7 & 51.4 & 72.9 \\
& More than 5 & 58 & 26.7 & 27.1 & 100.0 \\
& passages & & & & \\
Missing & Total & 214 & 98.6 & 100.0 & \\
& System & 3 & 1.4 & & \\
& Total & 217 & 100.0 & & \\
\hline
\end{tabular}

The outcomes show 1.4\% answered 'None', 19.8\% answered '1-2 passages', 50.7\% answered ' $3-5$ passages' and $26.7 \%$ answered 'More than 5 passages'. Hence, majority of the learners wrote 3-5 passages in one school term.

\section{Question 5}

The fifth question asked the respondents about the most difficult component that hinders their English writing during their primary school.

Table 5: What Is The Most Difficult Factor That Hinders Your English Writing?

\begin{tabular}{cccccc}
\hline & & Frequency & Percent & $\begin{array}{c}\text { Valid } \\
\text { Percent }\end{array}$ & $\begin{array}{c}\text { Cumulative } \\
\text { Percent }\end{array}$ \\
\hline Valid & Grammar & 57 & 26.3 & 26.6 & 26.6 \\
& Vocabulary & 123 & 56.7 & 57.5 & 84.1 \\
& Cultural differences & 23 & 10.6 & 10.7 & 94.9 \\
& between Malay and & & & & \\
& English & & & & \\
& Writing technique & 11 & 5.1 & 5.1 & 100.0 \\
Missing & Total & 214 & 98.6 & 100.0 & \\
& System & 3 & 1.4 & & \\
& Total & 217 & 100.0 & & \\
\hline
\end{tabular}

The outcomes show 26.3\% answered 'Grammar', 56.7\% answered 'Vocabulary', 10.6\% answered 'Cultural differences between Malay and English', and 5.1\% learners answered 'Writing technique'. Most of the Post-UPSR learners agree that vocabulary was the most difficult factor that hinders their writing.

\section{Discussions and Conclusion}

The results of the questionnaire analysis revealed the Post-UPSR high achiever learners' writing problems. In the study, Form One students from four of high ranking secondary 


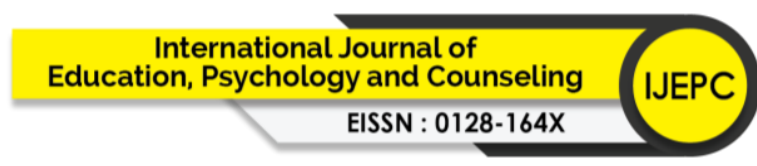

Volume 6 Issue 43 (November 2021) PP. 30-39

DOI 10.35631/IJEPC.643003

Special Issue: Issues and Challenges in English Education

schools were given the questionnaire in terms of writing problems. They had about six years of English learning practise in primary schools and had completed the UPSR examination. The data revealed that Malaysian ESL primary school learners struggle with writing tasks, particularly due to insufficient of vocabulary knowledge. As a result, it would be essential and required for language teaching to place a greater emphasis on improving vocabulary knowledge of the ESL primary school learners. The findings of the study will be valuable to ESL researchers and educators in assisting learners with their writing difficulties. Teachers or researchers can develop appropriate solutions to the issues once the writing issue has been identified.

\section{References}

Afrin, S. (2016). Writing Problems of Non-English Major Undergraduate Students in Bangladesh: An Observation. Open Journal of Social Sciences, 4, 104-115. https://doi.org/10.4236/jss.2016.43016

Asep, S. (2014). The Challenges in Teaching Writing Skill at Junior High School: Problems and Solutions.

Aziz, H. (2018). Miles to go in English Proficiency. New Straits Times.10 August: BI

Bayraktar, A. ve Seckin, S. (2012). Yazma güçlükleri ve öğretim yöntemleri. Ankara: Eğiten.

Can, B. ve Altunaş Yavuz, S. (2017). Okuma-yazma güçlüğü: Kimin için? Uşak Üniversitesi Eğitim Araştırmaları Dergisi, 3(2), 86-113.

Cresswell JW, Plano Clark VL. Designing and conducting mixed method research. $2^{\text {nd }}$ Sage; Thousand Oaks, CA: 2011.

DeLuca, C., \& Bellara, A. (2013). The current state of assessment education: Aligning policy, standards, and teacher education curriculum. Journal of Teacher Education, 64(4), 356-372.

Duran, Erol \& Karatas, Karatas (2019). Elimination of Writing Difficulty in Primary School: An Action Research. International Journal of Progressive Education, Volume 15 Number 5, 2019 (C) 2019 INASED. https://files.eric.ed.gov/fulltext/EJ1232516.pdf

Dunsmuir, S., Kyriacou, M., Batuwitage, S., Hinson, E., Ingram, V., \& O’Sullivan, S. (2015). An evaluation of the Writing Assessment Measure (WAM) for children's narrative writing. Assessing Writing, 23, 1-18.

Fareed, M., Ashraf, A., \& Bilal, M. (2016). ESL Learners' Writing Skills: Problems, Factors and Suggestions. Journal of Education and Social Sciences, 4, 81-92. https://doi.org/10.20547/jess0421604201

Gbollie, C., \& Keamu, H. P. (2017). Student Academic Performance: The Role of Motivation, Strategies, and Perceived Factors Hindering Liberian Junior and Senior High School Students Learning. Education Research International, 2017, Article ID: 1789084. https://doi.org/10.1155/2017/1789084

Ghabool, Neda., Mariadass \& Kashef, S. H. (2012). Investigating Malaysian ESL Students' Writing Problems on Conventions, Punctuation, and Language Use at Secondary School Level. Journal of Studies in Education, 2(3), 130-143. https://www.academia.edu/6303216/Investigating_Malaysian_ESL_Students_Writing _Problems_on_Conventions_Punctuation_and_Language_Use_at_Secondary_School _Level?email_work_card=view-paper

Hatch, J. A. (2002). Doing qualitative research in education settings. Albany: SUNY Press. 


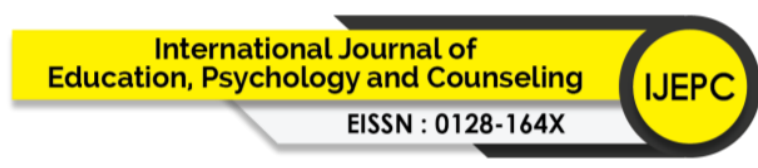

Volume 6 Issue 43 (November 2021) PP. 30-39

DOI 10.35631/IJEPC.643003

Special Issue: Issues and Challenges in English Education

Harun, Halipah \& Kabilan, Muhammad. (2020). Errors in writing made by Malaysian rural primary school pupils. Studies in English Language and Education. 7. 438-456. 10.24815/siele.v7i2.17009.

https://www.researchgate.net/publication/345938286_Errors_in_writing_made_by_M alaysian_rural_primary_school_pupils

Krishnasamy, J. (2015). Grammatical error analysis in writing of ESL diploma students. Asian Journal of Education and e-Learning, 3(1), 51-60.

Lim Kok Ien, Melor Md Yunus \& Mohamed Amin Embi (2017). Build Me Up: Overcoming Writing Problems among Pupils in a Rural Primary School in Belaga, Sarawak, Malaysia. Jurnal Pendidikan Humaniora. Volume 5, Number 1, March 2017, pp. 1-7. https://pdfs.semanticscholar.org/a492/1189f3d1c447a13a73512375536fbbe75b44.pdf

Maarof, N., \& Murat, M. (2013). Writing strategies used by ESL upper secondary school students. International Education Studies, 6(4), 47-55.

Maghsoudi, M., \& Haririan, J. (2013). The impact of brainstorming strategies Iranian EFL learners writing skill regarding their social class status. Journal of language and linguistics, 1(1), 60-67. http://dx.doi.org/10.11648/j.ijl1.s.20130101.20.

Malaysia Ministry of Education http://www.moe.gov.my

Melor, Norazah, Hadi, Amin \& Zeinab (2013). The use of information and communication technology (ICT) in teaching ESL writing skills. English Language Teaching, 6(7), 18. doi: 10.5539/elt.v6n7p1 https://eric.ed.gov/?id=EJ1077058

Ministry of Education Malaysia. (2013). Malaysian Education Blueprint 2013-2025. Kementerian Pendidikan Malaysia.

Moses, R. and Mohamad, M. (2019) Challenges Faced by Students and Teachers on Writing Skills in ESL Contexts: A Literature Review. Creative Education, 10, 3385-3391. doi: 10.4236/ce.2019.1013260. https://www.scirp.org/journal/paperinformation.aspx?paperid=97129

Nor Hani, Maslawati, Melor \& Azizah (2017). Identifying the Factors Contributing to Students' Difficulties in the English Language Learning. Creative Education, 8, 19992008. https://www.scirp.org/journal/paperinformation.aspx?paperid=79561

Nyang'au, B. N. (2014). Challenges students face in learning essay writing skills in English language in secondary schools in Manga District, Nyamira County, Kenya [Unpublished master's thesis]. Kenyatta University.

Ramasamy, R. M. M., \& Aziz, A. (2018). Peer Assessment in Writing Using Frog VLE in a Secondary School ESL Classroom. Creative Education. 9: 2265-2279.

Riswanto \& Putra, P. P. (2012). The use of mind mapping strategy in the teaching of writing at SMAN 3 Bengkulu, Indonesia. International journal of humanities and Social Science, 2(21), 60-68.

Selvaraj, M., \& Aziz, A. A. (2019). Systematic Review: Approaches in Teaching Writing Skill in ESL Classrooms. International Journal of Academic Research in Progressive Education and Development, 8(4), 450-473. https://hrmars.com/papers_submitted/6564/Systematic_Review_Approaches_in_Teac hing_Writing_Skill_in_ESL_Classrooms.pdf

Tse, A. (2014). A case study of grammatical errors made by Malaysian students. International Journal of Science Commerce and Humanities, 2(2), 154-160. 